\title{
Rевенст автісів: Relationship between personal characteristics of Assistant Technology Managers and perception of usefulness of Agricultural Technology Management Agency (ATMA)
}

M.B. Kudari and S.L. Patil

Article Chronicle :

Received :

04.06.2018;

Revised :

24.06.2018;

Accepted :

08.07.2018

Key Words :

Perception, ATM, ATMA
SUMMARY : The present study was conducted in Dharwad, Gadag, Belagavi, Haveri, Vijaypur, Bagalkot and Uttar Kannada districts of northern Karnataka. The total sample size for the study was 80 Assistant Technology Manager (ATMs). The Ex-post-facto research design was adopted for study. Findings of the study revealed that that majority $(81.25 \%)$ of the ATMs belonged to young age group, studied graduation $(52.50 \%)$, had less than 5 years of total experience, had participated one to two times of training $(55.00 \%)$, belonged to medium organizational climate $(61.25 \%)$, belonged to medium organizational commitment $(57.50 \%)$, belonged to medium job involvement $(61.25 \%)$, belonged to medium job satisfaction $(45.00 \%)$, belonged to high job stress $(51.25 \%)$, belonged to medium self confidence $(61.25 \%)$ and 63.75 per cent of ATMs belonged to medium job performance. Among eleven independent variables job involvement, education, training received and job performance showed positive and significant relationship with perception of usefulness of ATMA by ATMs. All the eleven independent variables taken together explained 49.70 per cent of the variation in the perception of usefulness of ATMA by ATMs.

How to cite this article : Kudari, M.B. and Patil, S.L. (2018). Relationship between personal characteristics of Assistant Technology Mangers and perception of usefulness of Agricultural Technology Management Agency (ATMA). Agric. Update, 13(3): 326-331; DOI : 10.15740/HAS/AU/13.3/326-331. Copyright@ 2018: Hind AgriHorticultural Society.
Author for correspondence :

\section{M.B. Kudari}

Department of Agricultural Extension Education, University of Agricultural Sciences, Dharwad (Karnataka) India

Email:manjukudari@ gmail.com

See end of the article for authors' affiliations 